\title{
2016-2018 Yılları Arasında Gerçekleşen Cinayet Vakalarına İlişkin Profil Analizi: Ankara Örneklemi
}

\author{
DOI: 10.26466/opus.706576
}

$*$

\author{
Ozan Kavsiraci* \\ * Dr. Öğretim Üyesi, Polis Akademisi Başkanlığı, Ankara/Türkiye \\ E-Posta: ozankavsiraci@gmail.com ORCID: 0000-0001-6351-3725
}

\section{Öz}

Suç olgusu, nedenleri ve sonuçları bakımından sosyolojik bir değerlendirmeyi gerekli kılmaktadır. Suç olgusunun alt başlıklarından biri olan öldürme fiili, gündelik hayatta oldukça nadir karşılaştığımız ve yaşama hakkını tehdit eden ağır bir eylemdir. Bu nedenle yaşam hakkına yönelik saldırıları en ağır suç olarak kabul etmek mümkündür. Bu çalışmanın amacl, Ankara polis sorumluluk bölgesinde gerçekleşen cinayet vakalarının nedenlerini, suça iten olası etkileri, cinayet şüphelisi ve maktullerine ait; cinsiyet, suç geçmişi, yaş, eğitim gibi değişkenlerin suçla ilişkisini analiz etmektir. Araştırmada kullanılan suç, şüpheli ve maktullere ilişkin veriler, Ankara Ill Emniyet Müdürlüğü bünyesinde yer alan Cinayet Büro Amirliği'nin yürüttü̈̆̈̈̈ çalışmalara ait bilgilerin analiz edilmesi sonucu elde edilmiştir. 2016-2018 yılları arasında Ankara polis sorumluluk bölgesinde gerçekleşen 239 cinayet vakası ve cinayet vakalar ile iliş̧ili olarak 389 şüpheli ve 267 maktul araştırma kapsamında değerlendirilmiştir. Cinayet vakalarına ilişkin sayısal verilerin analiz edilmesi için SPSS 22 programı kullanılmıştır. Bu çalışmada veriler tasniflenirken sınıflama ölçeği (nominal), verilerin sayısal dă̆̆llmlarının belirlenmesinde frekans analizi, ilgili her bir değgişken arasındaki ilişkinin incelenmesi için de çapraz tablolar (crosstab) kullanılmıştır. Araştırma kapsamında cinayetlerin \%92,7'sinin ruhsatsız silahlar ile gerçekleştiği, kadın cinayetlerinin gerçekleşme oranının \%20,6 olduğu, cinayet vakalarm $\% 37,2$ sinin alkol veya uyuşturucu madde kullanımı ile ilişkili olduğu, şüphelilerin \%58,6'sının geçmişte en az bir suç kaydının olduğu, öğrenim durumu lise ve daha altı olan şüphelilerin, toplam şüphelilerin \%94,6'sın oluşturduğu tespit edilmiştir. Araştırma sonucu kapsamda; bireysel silahlanma ve uyuşturucu veya uyarıcı maddelerin kullanılmasına yönelik önlemlerin tekrar gözden geçirilmesi, suçluların ıslah edilmesi, tekrar topluma kazandırılması noktasında da ceza adaleti sistemine yönelik iyileştirme çalışmalarına önem verilmesi gerektiği değerlendirilmektedir.

Anahtar Kelimeler: Cinayet, Şüpheli, Maktul 


\title{
Profiling Analysis Of Murder Cases Between 2016-2018: Ankara Sample
}

\begin{abstract}
The phenomenon of crime requires a sociological assessment in terms of its causes and consequences. Murder, which is one of the subheadings of the crime phenomenon is an extreme act because it threatens the right to life, which we rarely encounter in daily life. So, we can accept the attacks to right to life as a gross misconduct. The aim of this study which have been fulfilled in Ankara at the area of police responsibility is to analyze murder cases causes, possible effects pushing someone to crime and also analyze some factors related to criminal or victim such as; gender, criminal past, education or age. The data, which have been used within the scope of this research about crime, suspect or victim are obtained from Ankara Provincial Security Directorate's Homicide Department. In this study, between the years of 2016 and 2018, 239 murder cases have been studied, related to these cases 389 suspects and 267 victims were also evaluated. To analyze the case's data, SPSS 22 has been used. The programs; to classify gained data nominal scale, to detect numerical distribution frequency analyze and to investigate the relation among factors crosstabs have been used. Within the scope of that survey it is emerged that 92.7 percent of murder cases conducted with unregistered firearm, 20.6 percent of that case victims are women, 37.2 percent alcohol or drug related violence. The criminal's 58.6 percent have at least one criminal record. Totally 94.6 percent of that suspects have high school or low level education. As a result of the research; unregistered arms and the use of drugs or stimulants should be revised, rehabilitation of criminals and reintegration into society should have taken into consideration.
\end{abstract}

Keywords: Homicide, Suspect, Victim 


\section{Giriş}

Suç olgusu, hukuki olarak yasaların ihlali, sosyolojik açıdan insan haklarının ve ahlaki duyguların zedelenmesi olarak tanımlanmaktadır. Suç olgusu, suçlu, suçlu davranışları ve suça sürükleyen nedenleri kapsamaktadır. Suç olgusu nedenleri ve sonuçları bakımından sosyolojik bir değerlendirmeyi gerekli kılmaktadır. Bu noktada suç olgusunu analiz etmek, suç teşkil eden eylemlerin önlenmesi için de önem arz etmektedir. Suçlu davranışlar küçük yaşlardan itibaren başlamakta, işleniş sıklığı ve suçların ciddiyeti bakımından giderek artmaktadır. Ceza adalet sistemleri de suç olgusuna karşı kurumsallaşmış bir tepki olarak karşımıza çıkmaktadır. Ceza adalet sistemleri suç olgusuna karşı koruyucu ve önleyici bir fonksiyonu yerine getirmektedir (Şenel ve Şenel: 2018, s.208-209).

Suç olgusunun alt başlıklarından biri olan öldürme fiili, basit kabul edilebilecek bir eylem olmamakla birlikte yaşama hakkını tehdit eden ağır bir eylemdir. Öldürme eyleminin önünde ahlaki, hukuki kültürel, ekonomik, fiziksel ve psikolojik engeller bulunmaktadır. Bu nedenle öldürme fiilinin gerçekleşmesi için bireylerin bu konulardaki engelleri aşması gerekmektedir (Taştan ve Yıldız: 2018, s.27). Yaşam hakkı, insanların bütün haklardan yararlanabilmesi için ön şartı oluşturmaktadır. Bu çerçevede yaşam hakkına yönelik saldırılar aynı zamanda insanların diğer bütün haklarına da müdahaleyi içermektedir. Bu nedenle yaşam hakkına yönelik saldırıları en ağır suç olarak kabul etmek mümkündür.

Bu çalışmanın amacı, Ankara polis sorumluluk bölgesinde gerçekleşen cinayet vakalarının nedenlerini, suça iten olası etkileri, cinayet şüphelisi ve maktullerine ait, cinsiyet, suç geçmişi, yaş, eğitim gibi değişkenlerin suçla ilişkisini analiz etmektir. Bu kapsamda, Ankara polis sorumluluk bölgesinde gerçekleşen cinayet vakalarına yönelik suç nedenleri, maktul ve şüphelilerin kişisel özelliklerine ilişkin açıklamalar geliştirmek için suç, şüpheli ve maktullere ait veriler kayıt altına alınmış, elde edilen veriler analiz edilerek fiziki ve sosyal değişkenler arasındaki korelasyonlar incelenmiştir.

\section{Yöntem}

Bu çalışma tanımlayıcı türde olup, araştırmaya ilişkin veriler, 2016-2018 yılları arasındaki üç yıllık dönemi kapsamaktadır. Araştırmada kullanılan suç, 
şüpheli ve maktullere ilişkin veriler, Ankara İl Emniyet Müdürlüğü bünyesinde yer alan Cinayet Büro Amirliği' nin yürüttüğü çalışmalara ait verilerin analiz edilmesi sonucu elde edilmiştir. 2016-2018 yılları arasında Ankara polis sorumluluk bölgesinde gerçekleşen 239 cinayet vakası ve cinayet vakalarına ilişkin olarak 389 şüpheli ve 267 maktul araştırma kapsamında değerlendirilmiştir.

Verileri toplama aracı olarak araştırmacilar tarafından geliştirilen 20162018 yılları arasında her yıla ait ayrı olarak oluşturulan üç adet kayıt formu kullanılmıştır. Formlar, cinayet olayına ilişkin veri formu, şüphelilere ait veri formu ve maktullere ait veri formu olarak düzenlenmiştir. Cinayet olayına ilişki veri formu; yer, tarih, saat, suç silahı, suç nedeni, şüphelilerin yakalanma durumu ve suçta uyuşturucu madde etkisi alt başlıklarını içermektedir. Şüpheli ve maktullere ilişkin hazırlanan veri kayıt formaları aynı alt başlıklar kullanılarak hazırlanmışır. Şüpheli ve maktullere ilişkin veri kayıt formları; geçmiş suç kaydl, uyuşturucu bulundurma veya uyuşturucu ticaretinden geçmiş suç kaydı, cinsiyet, yaş, eğitim durumu, nüfus kaydı, ikamet yeri ve medeni hal alt başlıklarından oluşmaktadır.

Suç veri kayıt formu içerisinde yer alan alt başlıklardan suç nedeni başlığının kapsamı, suçun işleniş şeklinin araştırmacılar tarafından değerlendirilmesi sonucu oluşturulmuştur. Bu çerçevede trafikte, umuma açık alanlarda şüpheli ve maktuller arasında geçmiş bir bağlantıya rastlanılmadığı durumlarda gerçekleşen vakalar, kavga başlı̆̆ı altında değerlendirilmiştir. Maddi anlaşmazlık başlığı, taraflar arasında maddi bir gelir beklentisinin gerçekleşmemesi sonucu gerçekleşen cinayetler için kullanılmıştır. Aile içi anlaşmazlık başlığı, evli ve nişanlı bireyler, ebeveynler ve çocuklar arasında çıan üçüncü şahıslarla duygusal ilişki kurma dışındaki tartışmalar sonucu işlenen cinayet vakalarını kapsamaktadır. Husumet başlığı, taraflar arasında geçmişte yaşanan bir kavga veya tartışma sonucu kin gütme saiki ile işlenen cinayetleri ifade etmektedir. Namus başlığı, evli, nişanlı veya aralarında duygusal ilişki bulunan bireylerin üçüncü şahıslarla kurdukları duygusal ilişki sonucu gerçekleşen vakaları içermektedir. Gasp başlığı ise şahıslardan maddi değeri olan mal varlıklarını yasa dışı yollardan alma girişimi sonucunda gerçekleşen cinayetleri kapsamaktadır.

Ankara örnekleminde cinayet vakalarına ilişkin sayısal verilerin analiz edilmesi için SPSS 22 programı kullanılmıştır. Bu çalışmada veriler tasnifle- 
nirken sınıflama ölçeği (nominal), verilerin sayısal dağılımlarının belirlenmesinde frekans analizi, ilgili her bir değişken arasındaki ilişkinin incelenmesi için de çapraz tablolar (crosstab) kullanılmıştır.

Ankara polis birimlerince cinayet olaylarına ilişkin olarak tutulan verilere ulaşmak için Ankara İl Emniyet Müdürlüğü'ne yazılı başvuru yapılmıştır. Araştırmanın kapsamı, Ankara polis sorumluluk bölgesinde işlenen cinayet vakalarına ilişkin ilgili polis birimlerince elde edilen veriler ile sınırlı tutulmuştur. İlgili polis birimlerinde şüpheli ve maktullerin mesleklerine ait veriler yeterli olmadığı için araştırma kapsamına dâhil edilmemiştir.

\section{Bulgular}

Araştırma kapsamında verileri toplama aracı olarak yukarıda ifade edildiği üzere araştırmacılar tarafından geliştirilen 2016-2018 yılları arasında her yıla ait ayrı olarak oluşturulan üç adet kayıt formu kullanılmıştır. Formlar, cinayet olayına ilişkin veri formu, şüphelilere ait veri formu ve maktullere ait veri formu olarak düzenlenmiştir. Bu çerçevede araştırmaya ait verilerin daha sistematik ifade edilmesi için bulgular başlığı, cinayet olaylarına, şüphelilere ve maktullere ilişkin bulgular olmak üzere üç alt başlık altında incelenecektir.

\section{Cinayet Vakalarına İlişkin Bulgular}

Tablo 1. Ankara Polis Sorumluluk Bölgesinde İşlenen Cinayet Sayıları

\begin{tabular}{ll}
\hline Y11 & Olay Sayis1 \\
\hline $\mathbf{2 0 1 6}$ & 90 \\
\hline $\mathbf{2 0 1 7}$ & 83 \\
\hline $\mathbf{2 0 1 8}$ & 66 \\
\hline Toplam & 239 \\
\hline
\end{tabular}

Ankara örnekleminde 2016-2018 yıllarına ait üç yıllık dönem sürecinde polis sorumluluk bölgesinde toplam 239 cinayet vakası gerçekleşmiştir. İşlenen cinayet vakaları sırası ile 2016'da 90, 2017'de 83 ve 2018 yılında da 66 olarak gerçekleşmiştir. Cinayet vakalarının son üç yıllık dönemde azalma eğiliminde olduğu görülmektedir.

Tablo 2. İşlenen Cinayetlerin İlçelere Göre Dağılımı

\begin{tabular}{lll}
\hline İlçe & Olay Sayısı & Yüzdelik Dilim \\
\hline Alttndağ & 62 & $\% 25,9$ \\
\hline Çankaya & 48 & $\% 20$ \\
\hline Mamak & 46 & $\% 19,2$ \\
\hline Keçiören & 31 & $\% 12,9$ \\
\hline
\end{tabular}




\begin{tabular}{lll}
\hline Yenimahalle & 29 & $\% 12,1$ \\
\hline Etimesgut & 15 & $\% 6,2$ \\
\hline Pursaklar & 8 & $\% 3,3$ \\
\hline
\end{tabular}

Ankara'da işlenen cinayetlerin coğrafi dağılımına bakıldığında tablo 2'de ifade edildiği üzere 7 ilçe ön plana çıkmaktadır. Üç yıllık dönem içerisinde 62 vaka ile en çok cinayetin işlendiği ilçe Altındağ olmuştur. Altındağ ilçesini 48 vaka ile Çankaya, 46 vaka ile Mamak ve 31 vaka ile de Keçiören takip etmektedir.

Tablo 3. İşlenen Cinayetlerin Mevsimsel Dağılımı

\begin{tabular}{lll}
\hline Cinayet Saati & Olay Sayısı & Yüzdelik Dilim \\
\hline Kıs & 40 & $\% 20,9$ \\
\hline İlkbahar & 57 & $\% 23,9$ \\
\hline Yaz & 67 & $\% 28,1$ \\
\hline Sonbahar & 65 & $\% 27,2$ \\
\hline
\end{tabular}

Cinayet vakalarının mevsimsel dağılımında, yaz mevsimi en çok cinayetin işlendiği zaman dilimi olarak karşımıza çıkmaktadır. Yaz ayından sonra işlenen cinayet vakalarının sayısına göre sıra ile sonbahar, ilkbahar ve kış mevsimleri gelmektedir. Zaman dilimi olarak aylar temel alındığında ise ekim ayı 32 vaka ile ilk sırada gelmektedir. Ekim ayını sırası ile 28 vaka ile mart, 26 vaka ile haziran ve 25 vaka ile temmuz ayları takip etmektedir. En çok cinayet vakalarının görüldüğü üç ilçe temel alındığında ise; Altındağ' da temmuz, Çankaya'da aralık, Mamak'ta da haziran ayında en fazla cinayet vakası gerçekleşmiştir.

Tablo 4. İşlenen Cinayetlerin Saat Aralığı

\begin{tabular}{lll}
\hline Cinayet Saati & Olay Sayısı & Yüzdelik Dilim \\
\hline $\mathbf{0 6 - 1 2}$ & 40 & $\% 16,7$ \\
\hline $\mathbf{1 2 - 1 8}$ & 43 & $\% 18,0$ \\
\hline $\mathbf{1 8 - 2 4}$ & 92 & $\% 38,5$ \\
\hline $\mathbf{2 4 - 0 6}$ & 64 & $\% 26,8$ \\
\hline
\end{tabular}

Tablo 4' te akşam saatlerinde işlenen cinayet vakalarının gündüz saatlerine oranla daha fazla gerçekleştiği görülmektedir. 18-24 saatleri arasında toplam cinayet vakalarının \% 38,5'i gerçekleşmiştir. 24-06 saatleri aralığında da toplam vakaların \%26,8 gerçekleşmiştir. 18-06 saat aralığı temel alındığında ise toplam cinayetlerin $\% 65,3$ 'ü gerçekleşmiştir. 
İlçe ve zaman değişkenleri birlikte ele alındığında en çok cinayet vakasının görüldüğü Altındağ, Çankaya ve Mamak'ta cinayetlerin akşam saatlerinde işlenme sayısı şu şekildedir: Altındağ'da 62 vakanın 40'ı, Çankaya'da 48 vakanın 39'u, Mamak'ta da 46 vakanın 28'i 18-06 saatleri aralığında gerçekleşmiştir. Cinayet vakalarının görülme sayısı kapsamında 4. Sırada yer alan Keçiören'de ise 31 vakanın 28'i 18-06 saatleri arasında gerçekleşmiştir. Başka bir ifade ile Keçiören'de cinayetler, \%90 gibi yüksek bir oranla akşam saatlerinde gerçekleşmiştir.

Tablo 5. Cinayet Aletleri

\begin{tabular}{lll}
\hline Cinayet Aleti & Olay Sayısı & Yüzdelik Dilim \\
\hline Ateşli Silah & 164 & $\% 68,6$ \\
\hline Kesici-Delici Alet & 52 & $\% 21,8$ \\
\hline Künt Cisim veya Boğma & 23 & $\% 9,2$ \\
\hline
\end{tabular}

Tablo 5, Ankara polis sorumluluk bölgesinde işlenen cinayetlerin, hangi suç aleti ile gerçekleştiğini ifade etmektedir. Bu çerçevede toplam 239 cinayet vakasının 164'ü ateşli silah, 52'si kesici-delici alet ve 23'ü de künt cisimle darbe ya da boğma sureti ile gerçekleşmiştir. Tablo 5 'te elde edilen veriler bireysel silahlanmaya yönelik önlemlerin değerlendirilmesi gerektiğine işaret etmektedir. Bireysel silahlanma dünya geneline yayılmış önemli bir sorundur. Dünya genelindeki silahlarm $\% 74^{\prime}$ ü sivillere aittir ve bu oran sivillerin elinde silahlı kuvvetlerden daha fazla silah olduğunu göstermektedir. Bu çerçevede can ve mal güvenliğimizi sağlamakla görevli kolluk kuvvetlerinin sahip olduğundan daha fazla silahın sivillerin elinde olması bireysel silahlanmayı toplumsal güvenlik problemi haline getirmektedir (Orhan ve Yeter, 2019: 131).

Ankara'da toplam cinayetlerin $\% 68,6$ 'sı ateşli silah kullanılarak gerçekleşmiş̧ir. Toplam ateşli silah ile işlenen cinayetler \%30 oran ile en fazla Altındağ ilçesinde görülmektedir. Kesici-delici alet ile işlenen cinayetler Çankaya ve Mamak ilçelerinde eşit ve \%21 oranla en fazla sayıda görülmektedir. Künt cisimle darbe ya da boğma sureti ile işlenen cinayetlerin \%35 gibi büyük bir oranı da Keçiören ilçesinde gerçekleşmiştir.

En fazla cinayet vakasının görüldüğü 4 ilçede ise görünüm şu şekildedir: Altındağ'da 62 vakanın 49'u ateşli silah, 10'u kesici-delici alet ve 3'ü de künt cisimle darbe ya da boğma sureti ile gerçekleşmiştir. Çankaya' da 48 vakanın 35 'i ateşli silah, 11'i kesici-delici alet ve 2'si de künt cisimle darbe ya da boğma 
sureti ile gerçekleşmiştir. Mamak'ta 46 vakanın 32'si ateşli silah, 11'i kesicidelici alet ve 3'ü de künt cisimle darbe ya da boğma sureti ile gerçekleşmiştir. Keçiören'de 31 vakanın 17'si ateşli silah, 6'sı kesici-delici alet ve 8'i de künt cisimle darbe ya da boğma sureti ile gerçekleşmiştir.

Tablo 6. İşlenen Cinayetlerde Kullanılan Ateşli Silahların Ruhsat Durumu

\begin{tabular}{lll}
\hline Ruhsat Durumu & Olay Sayısı & Yüzdelik Dilim \\
\hline Ruhsatlı & 12 & $\% 7,3$ \\
\hline Ruhsatsız & 152 & $\% 92,7$ \\
\hline
\end{tabular}

Ateşli silah ile işlenen 164 cinayetin 152'si başka bir ifade ile \%92,7'si ruhsatsız silahlar ile gerçekleşmiştir. Bu sonuç bireysel silahlanmanın arttı̆̆ına ve bireylerin kayıtsız silahlara kolaylıkla ulaştığına işaret etmektedir.

Tablo 7. İşlenen Cinayet Olaylarının Nedenleri

\begin{tabular}{lll}
\hline Suç Nedeni & Olay Sayısı & Yüzdelik Dilim \\
\hline Kavga & 74 & $\% 31$ \\
\hline Namus & 51 & $\%$ 21,3 \\
\hline Maddi Anlaşmazlık & 44 & $\% 18,5$ \\
\hline Aile içi Anlaşmazlık & 36 & $\%$ 15,1 \\
\hline Husumet & 18 & $\%$ 7,6 \\
\hline Gasp & 7 & $\% 2,9$ \\
\hline Meskûn Mahalde Rastgele Ateş Etmek & 3 & $\% 1,2$ \\
\hline Psikolojik Rahatsılık & 1 & $\% 0,4$ \\
\hline Mavi Balina & 1 & $\% 0,4$ \\
\hline Faili Meçhul (Nedeni Bilinmiyor) & 4 & $\% 1,6$ \\
\hline
\end{tabular}

Ankara'da işlenen cinayetler Tablo 7'de ifade edildiği üzere çoğunlukla kavga sebebi ile gerçekleşmektedir. Kavgayı sırası ile namus, maddi anlaşmazlık, aile içi anlaşmazlık ve husumet nedenleri ile işlenen cinayetler takip etmektedir. Kavga sebebi sonucu işlenen cinayetler en fazla Çankaya ilçesinde, Namus ve maddi anlaşmazlık nedeni ile işlenen cinayetler en fazla Altındağ, aile içi anlaşmazlık nedeni ile işlenen cinayetler en fazla Mamak ve Çankaya ilçelerinde gerçekleşmiştir.

Kavga nedeniyle işlenen cinayetlerin \%76'sı, namus nedeniyle işlenene cinayetlerin \%59'u, maddi anlaşmazlık nedeniyle işlenen cinayetlerin \%57'si, aile içi anlaşmazlık nedeniyle işlenen cinayetlerin \%67'si ve husumet nedeniyle işlenen cinayetlerin \%62'si 18-06 saatleri arasında gerçekleşmiştir.

Kavga nedeniyle işlenen cinayetlerin \%72'si, namus nedeniyle işlenene cinayetlerin $\% 73$ 'ü, maddi anlaşmazlık nedeniyle işlenen cinayetlerin \%66'sı, 
aile içi anlaşmazlık nedeniyle işlenen cinayetlerin $\% 53$ ü ve husumet nedeniyle işlenen cinayetlerin \%83'ü ateşli silah ile gerçekleşmiştir.

Tablo 8. İşlenen Cinayetlerde Alkol veya Uyuşturucu Madde Etkisi

\begin{tabular}{lll}
\hline Alkol veya Uyuşturucu Madde Etkisi & Olay Sayısı & Yüzdelik Dilim \\
\hline Alkol veya Uyuşturucu Madde Etkisi Var & 89 & $\% 37,2$ \\
\hline Alkol veya Uyuşturucu Madde Etkisi Yok & 150 & $\% 62,8$ \\
\hline
\end{tabular}

Cinayet vakalarına ilişkin veriler incelenerek, vakaların gerçekleşmesinde alkol veya uyuşturucu madde kullanımının etkisi araştırılmış ve toplam 239 vakanın 89'unda uyuşturucu madde veya alkol kullanımı sonucunda cinayetlerin işlendiği tespit edilmiştir. Ankara'da işlenen cinayet vakaların \%37,2 si alkol veya uyuşturucu madde kullanımı ile ilişkilidir.

Tablo 9. Cinayet Nedenleri ile Alkol ve Uyuşturucu Madde Kullanımı İlişkisi

\begin{tabular}{llll}
\hline Suç Nedeni & $\begin{array}{l}\text { Alkol ve Uyuşturucu } \\
\text { Madde Etkisi Var }\end{array}$ & $\begin{array}{l}\text { Alkol ve Uyuşturucu } \\
\text { Madde Etkisi Yok }\end{array}$ & $\begin{array}{l}\text { Toplam } \\
\text { Olay } \\
\text { Sayısı }\end{array}$ \\
\hline Kavga & 39 & 35 & 74 \\
\hline Namus & 10 & 41 & 51 \\
\hline Maddi Anlaşmazlık & 20 & 24 & 44 \\
\hline Aile içi Anlaşmazlık & 12 & 24 & 36 \\
\hline Husumet & 5 & 13 & 18 \\
\hline Gasp & 3 & 4 & 7 \\
\hline Meskûn Mahalde Rastgele Ateş Etmek & 0 & 2 & 2 \\
\hline Psikolojik Rahatsızlık & 0 & 1 & 1 \\
\hline Mavi Balina & 0 & 1 & 1 \\
\hline
\end{tabular}

Kavga sebebi ile işlenen cinayetlerin \%53'ü alkol veya uyuşturucu madde etkisinde işlenmiştir. Diğer cinayet nedenlerinde ise alkol veya uyuşturucu madde etkisi oranları şu şekildedir: Maddi anlaşmazlık \%45, aile içi anlaşmazlık \%33, husumet $\% 28$ ve namus $\% 20$ 'dir. Tablo 9'da ifade edildiği üzere kavga nedeniyle işlenen cinayetleri, uyuşturucu madde veya alkol kullanımının etkilediğini söylemek mümkündür.

Tablo 10. İşlenen Cinayetlerde Faillerin Yakalanma Durumu

\begin{tabular}{lll}
\hline Failin Yakalanma Durumu & Olay Sayısı & Yüzdelik Dilim \\
\hline Faili Yakalandı & 231 & $\%$ 96,7 \\
\hline Faili Yakalanamadı & 8 & $\%$ 3,3 \\
\hline
\end{tabular}


Ankara'da üç yıllık dönemde 239 olarak gerçekleşen toplam cinayet vakasının 231 şüphelisi görevli polis birimlerince yakalanmış, 8 firari şüphelinin yakalanması için ilgili polis birimlerinin çalışmaları devam etmektedir. Cinayet şüphelilerinin yakalanması noktasında polisin \% 96,7 başarı yüzdesine sahip olduğu görülmektedir. Yakalama çalışmaları devam eden firari şüphelilerin 3'ü Altındağ, 2'si Mamak, 2'si Pursaklar ve 1 tanesi de Çankaya'da işlenen cinayetlerinden aranmaktadır.

\section{Şüphelilere İlişkin Bulgular}

Tablo 11. Şüphelilerin Suç Geçmişi

\begin{tabular}{lll}
\hline Geçmiş Suç Kaydı & Şüpheli Sayısı & Yüzdelik Dilim \\
\hline Geçmiş Suç Kaydı Var & 228 & $\%$ 58,6 \\
\hline Geçmiş Suç Kaydı Yok & 161 & $\%$ 41,4 \\
\hline
\end{tabular}

Ankara polis sorumluluk bölgesinde işlenen 239 cinayet vakasına ait soruşturma dosyasında, toplam 389 şüpheli incelenmiş ve şüphelilerin $\% 58,6$ 'sının geçmişte en az bir suç kaydının olduğu tespit edilmiştir. Geçmiş suç kaydı olan bireylerin \%57'si bekâr ve \%43'ü de evlidir. Geçmiş suç kaydı olan şüphelilerin \%68'i Ankara dışında başka bir il nüfusuna kayıtlı iken $\% 94$ 'ü Ankara'da ikamet etmektedir.

Şüphelilere ilişkin yapılan incelemelerde çok sayıda 50 ve üstü sayıda geçmiş suç kaydı olanlara rastlanılmıştır. Tablo 11 verilerine göre, suç işlemiş bireylerin sslah edilmesine yönelik sistemlerin tekrar değerlendirilmesi gerektiğini söylemek mümkündür.

Tablo 12. Şüphelilerin Cinsiyet Dağılımı

\begin{tabular}{lll}
\hline Cinsiyet & Şüpheli Sayısı & Yüzdelik Dilim \\
\hline Erkek & 377 & $\% 96,9$ \\
\hline Kadın & 12 & $\% 3,1$ \\
\hline
\end{tabular}

389 cinayet şüphelisinin 377'si erkek ve 12'si de kadındır. 377 erkek şüphelinin \%60'ının (224), 12 kadın şüphelinin de \%33'ünün (4) geçmişte en az bir suç kaydı bulunmaktadır. 
Tablo 13. Şüphelilerin Yaş Aralığı Dağılımı

\begin{tabular}{lll}
\hline Yaş Aralığı & Şüpheli Sayısı & Yüzdelik Dilim \\
\hline 18 Yaş Altı & 30 & $\% 7,7$ \\
\hline 18-24 Yaş & 98 & $\% 25,2$ \\
\hline 25-31 Yaş & 92 & $\% 23,7$ \\
\hline 32-38 Yaş & 71 & $\% 18,3$ \\
\hline 39-45 Yaş & 53 & $\% 13,6$ \\
\hline 45 Yaş Üstü & 45 & $\% 11,6$ \\
\hline
\end{tabular}

Cinayet şüphelilerinin \%25,2'si 18-24, \%23,7'si de 25-31 yaş aralığındandır. 18-31 yaş aralığındaki şüphelilerin toplam şüpheli sayısına oranı ise $\% 48,9^{\prime}$ dur. Şüphelilerin yaş aralığına göre geçmiş suç kayıtlarının oranı ise şu şekildedir:

18 yaş altındaki şüphelilerden \%47'sinin, 18-24 yaş aralığındaki şüphelilerden \%64'nün, 25-31 yaş aralığındaki şüphelilerden \%58'nin, 32-38 yaş aralığındaki şüphelilerden \%68'inin, 39-45 yaş aralığındaki şüphelilerden $\% 48$ 'nin ve 46 yaş ve üstü şüphelilerden $\% 56$ 'sının geçmişte en az bir suç kaydı bulunmaktadır.

Tablo 14. Şüphelilerin Eğitim Durumu

\begin{tabular}{lll}
\hline Eğitim Durumu & Şüpheli Sayısı & Yüzdelik Dilim \\
\hline İlköğretim & 189 & $\% 48,6$ \\
\hline Lise & 179 & $\% 46$ \\
\hline Üniversite & 18 & $\% 4,6$ \\
\hline Lisansüstü & 3 & $\% 0,8$ \\
\hline
\end{tabular}

Cinayet şüphelilerinin eğitim durumları incelendiğinde; eğitim seviyesinin artması ile cinayet şüpheli sayısında azalış gerçekleştiği görülmektedir. Cinayet şüphelilerinin \%48,6'sı (189) ilköğretim mezunu veya ilköğretimden terk, \%46'sı (179) lise mezunu, \%4,6's1 (18) ön lisans veya lisans mezunu ve $\% 0,8^{\prime} i$ (3) de lisansüstü mezunudur.

189 ilköğretim mezunu veya ilköğretimi terk eden cinayet şüphelilerinden \%57'sinin (108), 179 lise mezunu şüphelinin \%63'nün (112), 18 üniversite mezunu şüphelinin \%39'nun (7) ve 3 lisansüstü eğitimden mezun şüphelinin \%33'nün (1) geçmişte en az bir suç kaydı bulunmaktadır.

Tablo 15. Şüphelilerin Uyuşturucu Bulundurma veya Ticaretine İlişkin Suç Geçmişi

\begin{tabular}{lll}
\hline Uyuşturucuya İlişkin Suç Kaydı & Şüpheli Sayısı & Yüzdelik Dilim \\
\hline Uyuşturucuya İlişkin Suç Kaydı Var & 61 & $\% 15,7$ \\
\hline Uyuşturucuya İlişkin Suç Kaydı Yok & 328 & $\%$ 84,3 \\
\hline
\end{tabular}


389 cinayet şüphelisinin \%15,7'sinin (61) uyuşturucu kullanma veya ticaretinden suç kaydı bulunmaktadır. Bu oran suç kaydı bulunan şüpheliler arasında ise şu şekildedir: 228 suç kaydı bulunan şüphelinin \%28'inin uyuşturucu kullanma veya ticaretinden suç kaydı bulunmaktadır. Uyuşturucu kullanma veya ticaretinden suç kaydı bulunan şüphelilerin tamamı erkektir. Kadın şüphelilerden uyuşturucu suçlarından kaydı olanlara rastlanılmamıştır.

18 yaş altındaki şüphelilerden \%20'sinin, 18-24 yaş aralığındaki şüphelilerden \%20'sinin, 24-31 yaş aralığındaki şüphelilerden \%18'nin, 32-38 yaş aralığındaki şüphelilerden \%20'sinin, 39-45 yaş aralığındaki şüphelilerden \%4'ünün ve 46 yaş ve üstü şüphelilerden \%4'nün uyuşturucu suçlarından en az bir suç kaydı bulunmaktadır.

189 ilköğretim mezunu veya ilköğretimi terk eden cinayet şüphelilerinden 29'nun, 179 lise mezunu şüphelinin 30'unun, 18 üniversite mezunu şüpheliden 1'nin ve 3 lisansüstü eğitimden mezun şüphelinin 1'nin uyuşturucu suçlarından en az bir suç kaydı bulunmaktadır.

Uyuşturucu suçlarından kaydı olan şüphelilerin \%70'i Ankara dişında başka bir il nüfusuna kayıtlı iken \%97'si Ankara'da ikamet etmektedir. Uyuşturucu suçlarından kaydı bulunan şüphelilerin \%61'i bekârdır.

\section{Maktullere İlişkin Bulgular}

Tablo 16. Maktullerin Suç Geçmişi

\begin{tabular}{lll}
\hline Geçmiş Suç Kaydı & Maktul Sayısı & Yüzdelik Dilim \\
\hline Geçmiş Suç Kaydı Var & 114 & $\%$ 42,7 \\
\hline Geçmiş Suç Kaydı Yok & 153 & $\%$ 57,3 \\
\hline
\end{tabular}

Ankara polis sorumluluk bölgesinde işlenen 239 cinayet vakasına ait soruşturma dosyasında, toplam 267 mağdur incelenmiş ve maktullerin \%42,7'sinin geçmişte en az bir suç kaydının olduğu tespit edilmiştir. Geçmiş suç kaydı olan bireylerin \%61'i bekâr ve \%39'u de evlidir. Geçmiş suç kaydı olan maktullerin \%70'i Ankara dışında başka bir il nüfusuna kayıtlı iken \%96'sı Ankara'da ikamet etmektedir. Tablo 16 verilerine göre, cinayet maktullerinin de cinayet şüphelilerine benzer oranda geçmişte önemli oranda suç kayıtları olduğu görülmektedir.

Tablo 17. Maktullerin Cinsiyet Dağılımı

\begin{tabular}{lll}
\hline Cinsiyet & Maktul Sayısı & Yüzdelik Dilim \\
\hline Erkek & 212 & $\%$ 79,4 \\
\hline Kadın & 55 & $\%$ 20,6 \\
\hline
\end{tabular}


267 cinayet maktulünün 212'si erkek ve 55'i de kadındır. Tablo 17 verilerine göre Ankara' da 2016-2018 yılları arasındaki 3 yıllık dönemde kadın cinayetleri oranının \%20,6 olduğu görülmektedir. 212 erkek maktulün \%51'inin (108), 55 kadın maktulün de \%11'inin (6) geçmişte en az bir suç kaydı bulunmaktadır.

Tablo 18. Maktullerin Yaş Aralığı Dă̆ılımı

\begin{tabular}{lll}
\hline Yaş Aralığı & Maktul Sayısı & Yüzdelik Dilim \\
\hline 18 Yaş Altı & 13 & $\%$ 4,9 \\
\hline 18-24 Yaş & 40 & $\%$ 15,0 \\
\hline 25-31 Yaş & 62 & $\%$ 23,2 \\
\hline 32-38 Yaş & 65 & $\%$ 24,3 \\
\hline 39-45 Yaş & 34 & $\% 12,7$ \\
\hline 45 Yaş Üstü & 53 & $\% 19,9$ \\
\hline
\end{tabular}

Cinayet maktullerinin \%23,2'si 24-31, \%24,3'ü de 32-38 yaş aralığındandır. 24-38 yaş aralığındaki maktullerin toplam maktul sayısına oranı ise \%47,5'dir. Avustralya'da 1 Temmuz 2005 ve 30 Haziran 2006 arasındaki süreçte işlenen cinayetlere yönelik yapılan araştırmada 303 maktul içerisinden, erkeklerde 25-29 yaş arası, kadınlarda ise 20-24 yaş arasının maktul olmada en yüksek riski taşıdığı tespit dilmiştir (Davies ve Mouzos, 2007, akt; Türk ve Yavuz, 2011, s.13). Bu görünüm çalışma sonuçları ile de benzerlik göstermektedir.

Maktullerin yaş aralığına göre geçmiş suç kayıtlarının oranı ise şu şekildedir: 18 yaş altındaki maktullerden \%8'sinin, 18-24 yaş aralığındaki maktullerden \%45'inin, 25-31 yaş aralığındaki şüphelilerden \%52'sinin, 32-38 yaş aralığındaki maktullerden \%46'sının, 39-45 yaş aralığındaki maktullerden \%41'nin ve 46 yaş ve üstü maktullerden \%36'sının geçmişte en az bir suç kaydı bulunmaktadır.

Tablo 19. Maktullerin Eğitim durumu

\begin{tabular}{lll}
\hline Eğitim Durumu & Maktul Sayısı & Yüzdelik Dilim \\
\hline Illköğretim & 165 & $\% 61,8$ \\
\hline Lise & 82 & $\% 30,7$ \\
\hline Üniversite & 20 & $\% 7,5$ \\
\hline
\end{tabular}

Cinayet maktullerinin eğitim durumları incelendiğinde; şüphelilerin eğitimine ilişkin tablo 14 verileri ile benzerlik gösterdiği görünmektedir. Eğitim seviyesinin artması ile cinayet maktulü sayısında azalış gerçekleşmektedir. 
Cinayet maktullerinin \%61,8'i (165) ilköğretim mezunu veya ilköğretimden terk, \%30,7'si (82) lise mezunu, \%7,5'i (20) ön lisans veya lisans mezunudur.

165 ilköğretim mezunu veya ilköğretimi terk eden cinayet maktulünün \%43'ünün (71), 82 lise mezunu maktulün \%45'nin (37) ve 20 üniversite mezunu maktulün \%39'nun (6) geçmişte en az bir suç kaydı bulunmaktadır.

Tablo 20. Maktullerin Uyuşturucu Bulundurma veya Ticaretine İlişkin Suç Geçmişi

\begin{tabular}{lll}
\hline Uyuşturucuya İlişkin Suç Kaydı & Maktul Sayısı & Yüzdelik Dilim \\
\hline Uyuşturucuya İlişkin Suç Kaydı Var & 38 & $\% 14,2$ \\
\hline Uyuşturucuya İlişkin Suç Kaydı Yok & 229 & $\% 85,8$ \\
\hline
\end{tabular}

267 cinayet maktulünün \%14,2'sinin (38) uyuşturucu kullanma veya ticaretinden suç kaydı bulunmaktadır. Bu oran suç kaydı bulunan maktuller arasinda ise şu şekildedir: 114 suç kaydı bulunan maktulün \%33'ünün uyuşturucu kullanma veya ticaretinden suç kaydı bulunmaktadır. Uyuşturucu kullanma veya ticaretinden suç kaydı bulunan maktullerin 35'i erkektir. Kadın maktullerden uyuşturucu suçlarından kaydı olanların sayısı ise 3'tür.

18 yaş altındaki maktullerden \%8'sinin, 18-24 yaş aralığındaki maktullerden \%25'inin, 24-31 yaş aralığındaki maktullerden \%16'sının, 32-38 yaş aralığındaki maktullerden \%20'sinin, 39-45 yaş aralığındaki maktullerden \%6's1nın ve 46 yaş ve üstü maktullerden \%4'nün uyuşturucu suçlarından en az bir suç kaydı bulunmaktadır.

165 ilköğretim mezunu veya ilköğretimi terk eden cinayet maktullerinden 20 'sinin, 82 lise mezunu maktulün 16'sının ve 20 üniversite mezunu maktulden 2'sinin uyuşturucu suçlarından en az bir suç kaydı bulunmaktadır.

Uyuşturucu suçlarından kaydı olan maktullerin \%80'i Ankara dışında başka bir il nüfusuna kayıtlı iken \%97'si Ankara'da ikamet etmektedir. Uyuşturucu suçlarından kaydı bulunan maktullerin \%74'ü bekârdır.

\section{Tartışma ve Sonuç}

Ankara polis sorumluluk bölgesi örnekleminde, 2016-2018 yıllarına ait üç yıllık dönemde toplam 239 cinayet vakası gerçekleşmiştir. İşlenen cinayet vakaları sırası ile 2016'da 90, 2017'de 83 ve 2018 yılında da 66 olarak gerçekleşmiştir. Cinayet vakalarının son üç yıllık dönemde azalma eğiliminde olduğu görülmektedir. Ankara'da üç yıllık dönem içerisinde 62 vaka ile en çok cinayetin işlendiği ilçe Altındağ olmuştur. Altındağ ilçesini 48 vaka ile Çankaya, 46 vaka ile Mamak takip etmektedir. Ankara'nın adı geçen üç ilçesinde işlenen 
cinayet vaka sayıları diğer ilçelerle kıyaslandığında önemli bir fark olduğu görülmektedir. Bu ilçelere yönelik önlemlerin değerlendirilmesi önem arz etmektedir. 239 olarak gerçekleşen toplam cinayet vakasının 231 şüphelisi görevli polis birimlerince yakalanmış, 8 firari şüphelinin yakalanması için ilgili polis birimlerinin çalışmaları devam etmektedir. Cinayet şüphelilerinin yakalanması noktasında polisin \% 96,7 başarı yüzdesine sahip olduğu görülmektedir.

239 cinayet vakasının $164^{\prime}$ ü ateşli silah, 52'si kesici-delici alet ve $23^{\prime}$ ü de künt cisimle darbe ya da boğma sureti ile gerçekleşmiştir. Ateşli silah ile işlenen 164 cinayetin de 152 'si başka bir ifade ile \%92,7'si ruhsatsız silahlar ile gerçekleşmiştir. Araştırma sonucu elde edilen veriler, bireysel silahlanmaya yönelik önlemlerin değerlendirilmesi gerektiğine işaret etmektedir. Bu çerçevede kayıtsı silah temin etme yöntemlerinin engellenmesine yönelik olarak internet satışlarında ve av silahı satın alma prosedürlerinde denetimin arttırılması ve kamu spotlarına önem verilmesi gerekmektedir.

Araştırma kapsamında akşam saatlerinde işlenen cinayet vakalarının gündüz saatlerine oranla daha fazla gerçekleştiği görülmektedir. 18-24 saatleri arasında toplam cinayet vakalarının \% 38,5'i, 24-06 saatleri aralığında da toplam vakaların \%26,8 gerçekleşmiştir. 18-06 saat aralığı temel alındığında ise toplam cinayetlerin \%65,3'ü gerçekleşmiştir. Ankara'nın Keçiören ilçesinde ise 31 vakanın 28'i 18-06 saatleri arasında gerçekleşmiştir. Başka bir ifade ile Keçiören'de cinayetler, \%90 gibi yüksek bir oranla akşam saatlerinde gerçekleşmiştir.

Ankara'da işlenen cinayetler çoğunlukla kavga sebebi ile gerçekleşmektedir. Kavgayı sırası ile namus, maddi anlaşmazlık, aile içi anlaşmazlık ve husumet nedenleri ile işlenen cinayetler takip etmektedir. Kavga sebebi sonucu işlenen cinayetler en fazla Çankaya ilçesinde görülmektedir. Kavga nedeniyle işlenen cinayetlerin \%76'sı 18-06 saatleri arasında gerçekleşmiş ve \%72'sinde ateşli silah kullanılmıştır.

Cinayet vakalarına ilişkin alkol veya uyuşturucu madde kullanımının etkisi araştırılmış ve toplam 239 vakanın 89'unda uyuşturucu madde veya alkol kullanımı sonucunda cinayetlerin işlendiği tespit edilmiştir. Ankara'da işlenen cinayet vakaların \%37,2 si alkol veya uyuşturucu madde kullanımı ile ilişkilidir. Kavga sebebi ile işlenen cinayetlerin \%53'ü alkol veya uyuşturucu madde etkisinde işlenmiştir. Ayrıca 228 suç kaydı bulunan şüphelinin \%28'inin uyuşturucu kullanma veya ticaretinden suç kaydı bulunmaktadır. 
114 suç kaydı bulunan maktulün ise \%33'ünün uyuşturucu kullanma veya ticaretinden suç kaydı bulunmaktadır. Uyuşturucu madde kullanımı veya ticaretinin cinayet olaylarında risk faktörü taşıdığı anlaşılmaktadır. Uyuşturucu suçlarından kaydı olan şüphelilerin \%70'i, maktullerin ise \%80'i Ankara dışında başka bir il nüfusuna kayıtlı iken \%97'si Ankara'da ikamet etmektedir.

Araştırma bulgularına bakıldığında şüphelilerin \%58,6'sının geçmişte en az bir suç kaydının olduğu tespit edilmiştir. Ayrıca şüphelilere ilişkin yapılan incelemelerde çok sayıda 50 ve üstü sayıda geçmiş suç kaydı olan şüphelilere rastlanılmıştır. 18 yaş altındaki şüphelilerden \%47'sinin, 18-24 yaş aralığındaki şüphelilerden \%64'nün, 25-31 yaş aralığındaki şüphelilerden \%58'nin, 32-38 yaş aralığındaki şüphelilerden \%68' inin, 39-45 yaş aralığındaki şüphelilerden \%48'nin ve 46 yaş ve üstü şüphelilerden $\% 56$ 'sının geçmişte en az bir suç kaydı bulunmaktadır. Maktullerin ise $\% 42,7^{\prime}$ sinin geçmişte en az bir suç kaydının olduğu tespit edilmiştir. Bu noktada suçlu bireylerin ıslah edilmesi ve tekrar topluma kazandırılması kapsamında ceza adaleti sistemine yönelik çalışmalar önem kazanmaktadır.

Cinayet şüphelilerinin \%48,6'sı ilköğretim mezunu veya ilköğretimden terk, \%46'sı ise lise mezunudur. Öğrenim durumu lise ve daha altı olan şüpheliler, toplam şüphelilerin \%94,6'sını oluşturmaktadır. Cinayet maktullerinin \%61,8'i ilköğretim mezunu veya ilköğretimden terk, \%30,7'si lise mezunudur. Öğrenim durumu lise ve daha altı olan maktuller, toplam maktullerin \%92,5'ini oluşturmaktadır. Bu noktada düşük eğitim seviyesinin, cinayet olaylarında risk faktörü olduğu anlaşılmaktadır.

Ankara örnekleminde 2016-2018 yılları arasında gerçekleşen kadın cinayetlerinin toplam cinayet olaylarına oran $\% 20,6$ ' dır. Kadın cinayetlerinin nedenleri arasında öne çıkan faktörler ise şunlardır:

- Aile içi, akrabalar ve maddi konular üzerine çıkan tartışmalar

- Boşanma sonrasında çocukların velayeti üzerine çıkan tartışmalar

- Duygusal birliktelik kurma tekliflerinin reddedilmesi

- Alkol veya uyuşturucu madde kullanımının etkisi

- Aldatılma düşüncesi 


\section{EXTENDED ABSTRACT}

\section{Profiling Analysis Of Murder Cases Between 2016-2018: Ankara Sample}

Ozan Kavsirac1

Police Academy

The phenomenon of crime is legally defined as a violation of the laws, and sociologically, damage to the human rights and moral sentiments. The phenomenon of crime includes criminal and criminal behaviors and the reasons leading to crime. It requires a sociological assessment in terms of the causes and consequences of crime phenomenon. At this point, analyzing the crime phenomenon is also important for the prevention of criminal acts. Criminal behavior starts from a young age, gradually increasing in terms of frequency of crimes and seriousness of crimes.

Although the act of killing is not an act that can be accepted as simple, it is a heavy action that we encounter very rarely in daily life and threatens the right to life. There are moral, legal, cultural, economic, physical and psychological obstacles to the act of killing. Therefore, for the purpose of the killing, individuals need to overcome the obstacles in these matters. The right to live is a prerequisite for people to benefit from all rights. In this context, attacks on the right to live also involve intervention in all other rights of people. For this reason, it is possible to accept the attacks on the right to live as the most serious crime.

The aim of this study is to analyze the causes of murder incidents that took place in the Ankara police responsibility area, the possible effects of crime, the relationship between the suspect and victims, gender, crime history, age and education. In this context, in order to develop explanations regarding the causes of crime and the personal characteristics of the victims and suspects in the Ankara police responsibility area, data on crime, suspects and victims were recorded, and the correlations between physical and social variables were examined by analyzing the obtained data.

This study is descriptive and the data related to the research covers the three-year period between 2016-2018. The data related to the crime, suspects and victims used in the research were obtained by analyzing the data of the 
studies carried out by the Homicide Bureau within the Ankara Provincial Police Department. 389 suspects and 267 victims were evaluated within the scope of 239 murder cases that took place in Ankara police responsibility area between 2016-2018. The SPSS 22 software was used to analyze numerical data on murder cases in the Ankara example. In this study, classification scale (nominal) was used when classifying the data, frequency analysis was used to determine the numerical distributions of the data, and crosstabs were used to examine the relationship between each variable.

A total of 239 murders occurred in the police responsibility area during the three-year period of the 2016-2018 period in the Ankara example. The murder cases were 90 in 2016, 83 in 2017 and 66 in 2018. It is seen that homicide cases tend to decrease in the last three-year period. Considering the geographical distribution of the murders committed in Ankara; the district where the most murder was committed with 62 cases was Altındag within the threeyear period. Altındağ is followed by Çankaya with 48 cases, Mamak with 46 cases and Keçiören with 31 cases.

It is observed that the cases of murder during the evening are more likely to occur than in the daytime hours. Between the hours of 18 and 24, 38.5\% of the total murder cases occurred. Between the hours of 00 and $06,26.8 \%$ of the total murder cases occurred. On the basis of the 18-06 hour interval, $65.3 \%$ of the total murders occurred. Of the 239 cases of murder, 164 were the firearms, 52 sharp-piercing tools, and 23 were dealt with blunt force trauma, or bluntforce strangeal. Of the 164 murders committed with firearms, 152 were, in other words, $92.7 \%$ of them were unlicensed guns. This result indicates that individual proliferation has increased and that individuals have easily reached unregistered weapons.

Murders committed in Ankara mostly occur due to a fight. The fight is followed by the murders committed due to honor, financial disagreement, domestic dispute and conflict. By examining the data related to murder cases, the effect of alcohol or drug use was investigated in the occurrence of the cases and it was determined that the murders were committed 89 out of 239 cases due to drug or alcohol usage. $37.2 \%$ of the murder cases committed in Ankara are related to alcohol or drug use.

In the investigation file of 239 murder cases committed in Ankara police responsibility area, a total of 389 suspects were examined and $58.6 \%$ of the suspects had at least one criminal record in the past. When the educational 
status of murder suspects is examined; It is observed that the number of murder suspects decreased with the increase in the level of education. 48.6\% (189) of murder suspects are primary school graduates or dropped out of primary education, $46 \%$ (179) are high school graduates, 4.6\% (18) associate or undergraduate graduates and $0.8 \%$ (3) is also a postgraduate. $15.7 \%$ (61) of 389 murder suspects have a criminal record of drug use or trafficking.

In the investigation file of 239 murder cases committed in Ankara police responsibility area, a total of 267 victims were examined and $42.7 \%$ of the victims were found to have at least one criminal record in the past. When the educational status of the murder victims are examined; it appears to be similar to the data on the education of the suspects. With the increase in the level of education, the number of murder victims decreases. $61.8 \%$ (165) of the murder victims are primary school graduates or dropped out of primary education, 30.7\% (82) are high school graduates, 7.5\% (20) are associate or undergraduate graduates. Of the 267 murder victims, $14.2 \%$ (38) had a criminal record of drug use or trafficking.

\section{Kaynakça / References}

Orhan, G., ve Yeter, B. Ö. (2019). Bir güvenlik sorunu olarak bireysel silahlanma: türkiye için durum değerlendirmesi ve politika alternatifleri. ASSAM Uluslararası Hakemli Dergi, 13. Uluslararası Kamu Yönetimi Sempozyumu Bildiri Özel Sayıs1, 130-145.

Şenel, M., ve Şenel, T. A. (2018). Kuramsal kriminoloji üzerine. Polis Akademisi Yayınları: Ankara.

Taştan, C., ve Yıldız, K. A. (2018). Dünyada ve Türkiye'de kadın cinayetleri 2016-20172018 verileri ve analizler. Polis Akademisi Yayınları: Ankara.

Türk B., ve Yavuz, F. M. (2011). Faili meçhul cinayetlerin ve mağdurlarının özellikleri. Türkiye klinikleri Adli Ttp ve Adli Bilimler Dergisi, 8(1), 12-22.

\section{Kaynakça Bilgisi / Citation Information}

Kavsıracı, O. (2020). 2016-2018 yillari arasinda gerçekleşen cinayet vakalarina ilişkin profil analizi: Ankara örneklemi. OPUS-Uluslararası Toplum Araştırmaları Dergisi, 16(32), 5015-5033. DOI: 10.26466/opus.706576 